\title{
有明海湾奥西部の干潟縁辺域における DO経年変動特性
}

\author{
徳永 貴久 1 ・田井 明 2 小元 克則 3 \\ 1正会員 独立行政法人 水産総合研究センター 西海区水産研究所（テ 851-2213 長崎県長崎市多以良町 \\ 1511-8) \\ E-mail:tokut@affrc.go.jp \\ 2正会員 九州大学高等研究院（干819-0395 福岡県福岡市西区元岡744番地） \\ E-mail:tai@civil.kyushu-u.ac.jp \\ 3独立行政法人 水産総合研究センター 西海区水産研究所（干851-2213 長崎県長崎市多以良町1511-8） \\ E-mail:kimoto@affrc.go.jp
}

\begin{abstract}
有明海湾奥西部の干潟縁辺域を中心に形成する貧酸素水塊の経年変動特性と潮流との関係を明らかにす るために2005年から2012年の夏季に流速および底層DO等の水質の現地観測を行った. 流速の調和解析を 行った結果, いずれの年も10分潮のうち $\mathrm{M}_{2}$ 潮が卓越しており，東西成分よりも北方成分が卓越していた. 各成分を合成した潮流振幅 $\left(\mathrm{M}_{2}\right)$ は2009年が大きく, 2006年と2012年が小さかった. 平均底層DOは2006 年および2012年が最も低く, 2009年が最も高い值を示した。潮流振幅 $\left(\mathrm{M}_{2}\right)$ と密度差，潮流振幅 $\left(\mathrm{M}_{2}\right)$ の3乗と平均底層DOのとの間には相関関係が見られたことから, 有明海湾奥西部の干潟縁辺域では, 生物 化学的作用のみならず淡水流入による河口循環流の形成とそれによる潮流振幅の変化が貧酸素水塊の形成 に重要な役割を果たしていることが示唆された.
\end{abstract}

Key Words :hypoxia, tidal current, stradification, estuarine circulation

\section{1. はじめに}

貧酸素水塊の形成は，二枚貝類をはじめとするベント スや生物生産構造に大きな影響を与えている（Diaz and Rosenberg ${ }^{1)}$, Nilsson and Rosenberg ${ }^{2)}$ ) . 特に, 貧酸素水塊 および無酸素水塊の形成と生態系との関係はヒステリシ スな関係があることが指摘されており，栄養塩負荷を削 減しても生態系は急激に回復されないこともあることが 明らかになっている (Kemp et al. ${ }^{3)}$ ) 。また, Kemp et al. ${ }^{3)}$ は流入負荷と貧酸素強度との関係を6区分（(a) Linear Recovery, (b) Recovery with Threshold, (c) Hysteresis, (d) Hysteresis with Threshold, (e) Shifting Baseline, (f) Shifting Baselie, Hysteresis, Threshold，）に分類した. 有明海における貧酸 素水塊の形成機構について速水ら ${ }^{4)}$ は，河川からの淡水 流入および河口循環流による高塩分水の底層貫入によっ て密度成層と高い酸素消費が重要な役割を果たすことを 明らかにしている。速水ら ${ }^{4} は ，$ 浅海定線調査データを 用いて，底層溶存酸素（以下，DO）の長期変動を解析 し，成層強度の影響を除いた底層DOは1970年代後半か ら減少しており, その原因として有機物濃度の増加とそ
れによる堆積物および懸濁物の酸素消費速度の増加を指 摘している.

有明海における流動については，小田巻5は2001年と 1973年の潮流観測結果を比較し，一方的な減衰傾向はみ られないことや場所によって強くなっているところもあ ることを明らかにしており，その理由として淡水流入条 件による河口循環流形成の違いによる可能性について言 及している.また, 地形の変化や月の昇降点運動に伴う 18.6年周期の潮汐変動（ $\mathrm{M}_{2}$ 潮）の低下が明らかになって いる $\left(\right.$ 田井ら $\left.{ }^{9}\right)$ 。さらに，万田ら ${ }^{7}$ は潮流減少は潮汐残 差流による移流や潮流による拡散などの物質輸送を弱め る効果と，それとは逆に潮流流速の減少によって密度成 層が強化されるために河口循環流の流速は増加している 可能性を指摘した. 流速と貧酸素水塊との関係について は，鉛直混合の観点から流速と密度成層の形成との関係 を明らかにしたものがほとんどであり，流速と貧酸素水 塊との関係を経年的に明らかにした研究例が少ない ${ }^{8)}$.

本研究は, 有明海奥部干潟縁辺域における現地観測結 果を用いて，有明海湾奥干潟縁辺域の潮流振幅 $\left(\mathrm{M}_{2}\right)$, 密度成層, 底層DOの経年変化から流速と貧酸素水塊の 


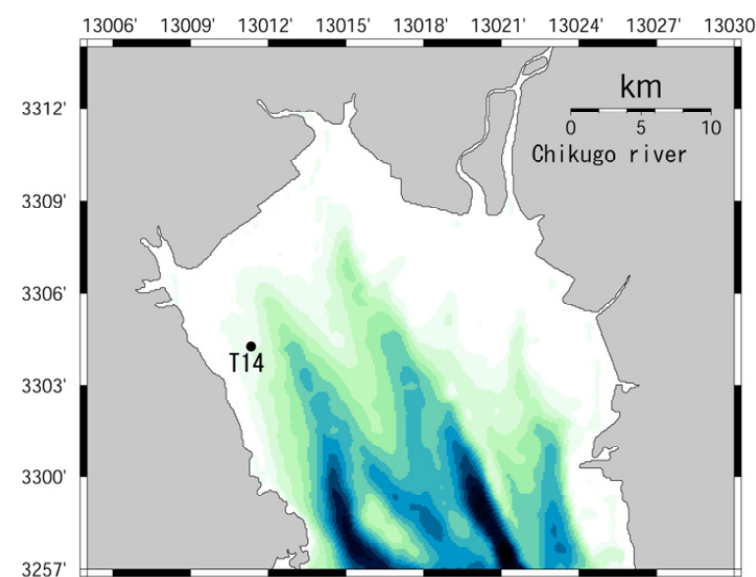

図-1 観測点

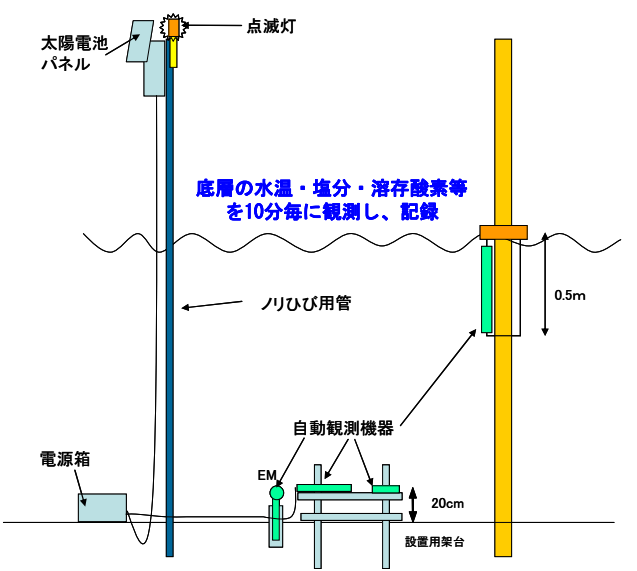

図-2 観測概要

表-1 T14における調和解析結果（2012年）

\begin{tabular}{cccc}
\hline 分潮 & 東西成分振幅 $(\mathrm{cm} / \mathrm{sec})$ & 南北成分振幅 $(\mathrm{cm} / \mathrm{sec})$ & $\mathrm{M}_{2}$ との比(南北成分) $(\%)$ \\
\hline 残差流 & 1.29 & 0.63 & \\
$\mathrm{M}_{2}$ & 3.94 & 6.05 & 100.0 \\
$\mathrm{~S}_{2}$ & 1.30 & 3.05 & 50.4 \\
$\mathrm{~K}_{1}$ & 0.64 & 0.65 & 10.8 \\
$\mathrm{O}_{1}$ & 0.43 & 0.44 & 7.2 \\
$\mathrm{Q}_{1}$ & 0.15 & 0.09 & 1.6 \\
$\mathrm{P}_{1}$ & 0.17 & 0.15 & 2.5 \\
$\mathrm{~N}_{2}$ & 0.76 & 1.55 & 25.7 \\
$\mathrm{~K}_{2}$ & 0.79 & 0.84 & 13.8 \\
$\mathrm{M}_{4}$ & 0.28 & 0.36 & 6.0 \\
$\mathrm{MS}_{4}$ & 0.37 & 0.39 & 6.4 \\
\hline
\end{tabular}

形成との関係性を明らかにすることを目的とする．本研 究は，平成17年度水産庁委託事業「貧酸素水塊漁業被害 防止対策」，平成18年度環境省請負業務「有明海貧酸素 水塊発生機構解明調査」，平成19年度～平成21年度環境 省請負業務「有明海貧酸素水塊発生機構実証調査」およ び平成22年度〜平成24年度環境省請負業務「有明海生態 系回復方策検討調查（二枚貝類の環境浄化機能解明調 查）」のデータを用いて解析した.

\section{2. 材料と方法}

2005 年から 2012 年の夏季に有明海湾奥西部海域の $\mathrm{T} 14$ （水深約 5m）（図-1）において 10 分毎に海面下 $0.5 \mathrm{~m}$ の水温および塩分, 海底から $0.2 \mathrm{~m}$ の流速および水 質の連続観測を行った（図-2）。電磁流速計（JFE アド バンテック, AEM-HR) , 多項目水質計 (Hydrolab MS5），DO 計（JFE アドバンテック，ADOW-CMP）が 用いられた。観測期間中は 1 週間に 1 回の清掃および測 器交換を行った. また， 1 週間に 1 回の頻度で多項目水 質計（JFE アドバンテック，AAQ-1183Hおよび AAQ-176） による水質の鉛直分布を計測し, 北原式採水器により海 面下 $1 \mathrm{~m}$ および海底上 $0.5 \mathrm{~m}$ で採水した. 採取された海水 は，懸濁物を除去した後に，サリノメータ（YEO-KAL，
SALINOMETER601Mk-IV）により塩分を分析した。また, DO 濃度はウインクラー法に従い自動分析装置

(Metrohm, 726) で分析した. 分析值により連続観測值 を補正した。補正は水温は基準となる水温計により補正 した. 塩分はサリノメータによる分析值により補正した. DO 飽和度は，ウィンクラー法による分析值を観測時の 水温と塩分を元に溶存酸素飽和度に換算し, 機器測定值 の溶存酸素飽和度を補正した。

2005 年から 2012 年までの夏季の期間について流速の 調和解析を行った. 調和解析はエラ一值を除去後, 一般 的に以下の式で表される潮流変動について未知係数 $a_{u 0}$, $a_{u 0}, a_{u i}, a_{v i}, b_{u i}, b_{v i}$ を最小自乗法を用いてデータにフィ ッテングすることにより行った.

$$
\begin{aligned}
& u(t)=a_{u 0}+\sum_{i=1}^{10} a_{u i} \cos \left(\frac{2 \pi}{T_{i}} t+b_{u i}\right) \\
& v(t)=a_{v 0}+\sum_{i=1}^{10} a_{v i} \cos \left(\frac{2 \pi}{T_{i}} t+b_{v i}\right)
\end{aligned}
$$

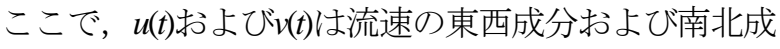
分， $a_{n i} ， a_{v i}$ はそれぞれ東西成分および南北成分の各分潮 の振幅， $T_{i}$ は各分潮の周期，t $t$ は時間， $b_{u i}, b_{v i}$ は東西成分 および南北成分の各分潮の遅角である. 87日間のデータ を用い (中野9) ，考慮した分潮数は10分潮 $\left(\mathrm{M}_{2}, \mathrm{~S}_{2}\right.$, $\left.\mathrm{K}_{1}, \mathrm{O}_{1}, \mathrm{Q}_{1}, \mathrm{P}_{1}, \mathrm{~N}_{2}, \mathrm{~K}_{2}, \mathrm{M}_{4}, \mathrm{MS}_{4}\right)$ である. 

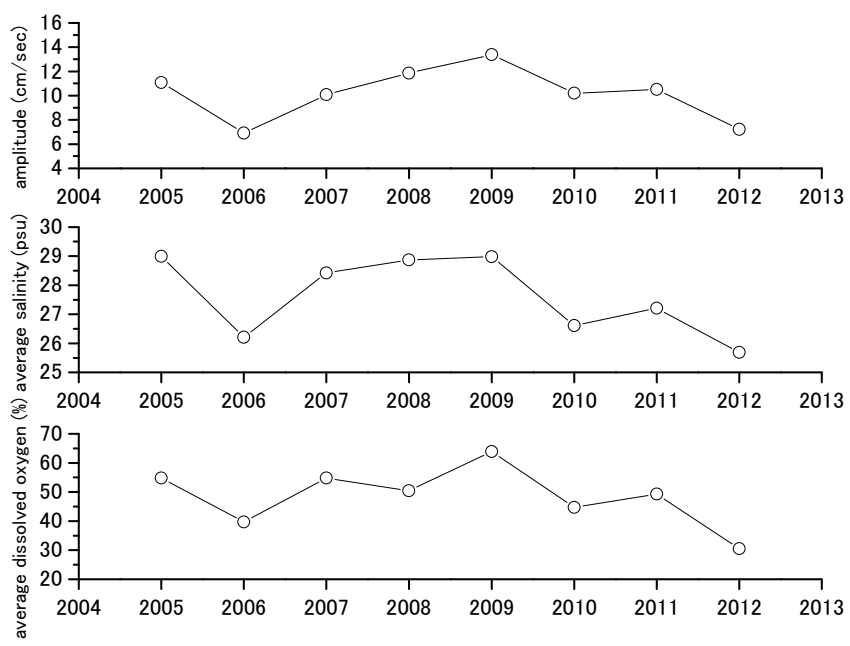

図-3 潮流振幅 $\left(\mathrm{M}_{2}\right)$ ，底層塩分および 底層 DO 飽和度の経年変化

\section{3. 結果}

\section{(1)調和解析結果と潮流振幅 $\left(M_{2}\right)$ の経年変動}

表-1はT14における2012年の調和解析結果（潮流振幅） および $\mathrm{M}_{2}$ を100とした場合の各分潮の振幅の割合を示す. 東西成分および南北成分いずれにおいても $\mathrm{M}_{2}$ が最も大 きく，南北成分が東西成分よりも大きな值を示した． $\mathrm{S}_{2}$, $\mathrm{K}_{1}, \mathrm{O}_{1}$ の南北成分も大きな值を示した， $\mathrm{M}_{2}$ の東西成分, 南北成分の振幅はそれぞれ $3.94 \mathrm{~cm} / \mathrm{sec}, 6.05 \mathrm{~cm} / \mathrm{sec}$ であり, $\mathrm{M}_{2}$ の振幅に対する $\mathrm{S}_{2}, \mathrm{~K}_{1}, \mathrm{O}_{1}$ の比は，それぞれ，50.4\%， 10.8\%，7.2\%であった． $\mathrm{M}_{2}$ の寄与が最も大きく，東西成 分よりも南北成分が大きい傾向は経年的に変化しなかっ た. 残差流成分は東西成分が $1.29 \mathrm{~cm} / \mathrm{sec}$, 南北成分が 0.63cm/secであった。また，2006年の残差流は $1.39 \mathrm{~cm} / \mathrm{sec，}$ 2009年は0.90cm/secであり，2009年が小さかった．残差流 は，北西方向を示し，既存知見 (速水ら ${ }^{4)}$ ) と同様に沖 から岸へ向から方向が卓越していた，図-3に東西成分お よび南北成分を合成した潮流振幅 $\left(\mathrm{M}_{2}\right)$ ，底層塩分お よび底層DO飽和度の経年変化を示す。2006年および 2012年の潮流振幅 $\left(\mathrm{M}_{2}\right)$ は最も小さく (約7 $\left.\mathrm{cm} / \mathrm{sec}\right)$ ，最 も大きくなったのは2009年（約14cm/sec）であり，経年 的な変動がみられた。田井らのが明らかにしたf值 $\times \mathrm{M}_{2}$ 潮 の潮汐振幅と潮流振幅 $\left(\mathrm{M}_{2}\right)$ の経年変化には相関関係 はみられなかった（図-4）。底層塩分，底層DO飽和度 は潮流振幅 $\left(\mathrm{M}_{2}\right)$ と同様な変動がみられた.

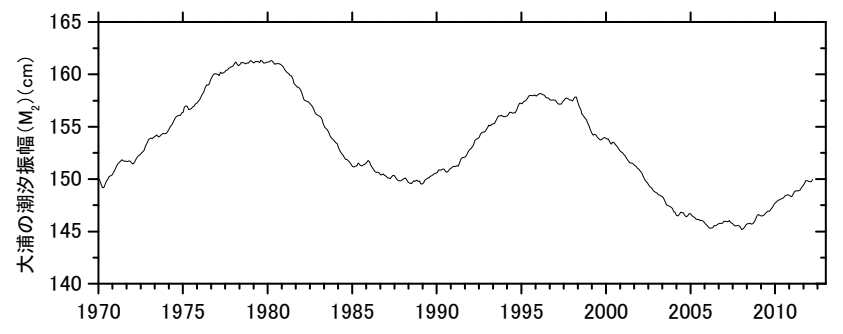

図-4 大浦における $\mathrm{f} \times$ 潮汐振幅 $\left(\mathrm{M}_{2}\right)$ の長期変動 (田井 ${ }^{6}$ )

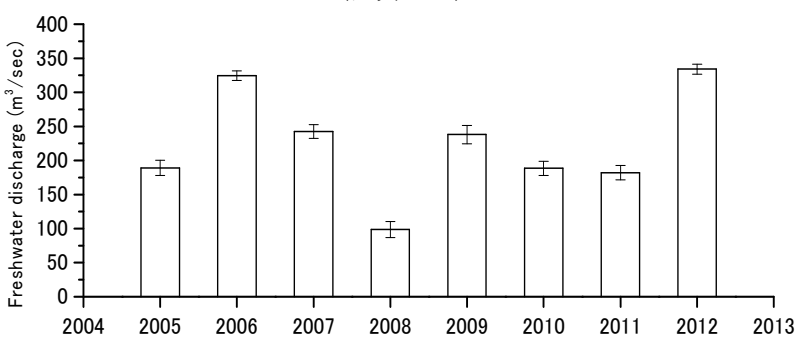

図-5 筑後川平均流量 (バーは標準誤差を表す)

\section{（2）淡水流入と密度成層の経年変化}

図-5に調和期間の筑後川平均流量の経年変化を示す. 2006 年および 2012 年が最も大きくそれぞれ $324 \mathrm{~m}^{3} / \mathrm{sec}$, $334 \mathrm{~m}^{3} / \mathrm{sec}$ であった. 環境省 ${ }^{10)}$ によると, 2006 年は, 7 月初め から中旬まで梅雨前線が停滞することが多く, 特に 4 日には 佐賀市で 85mm の降雨があった. また中旬から下旬にか恼て も梅雨前線の発達により降雨があった. 8 月上旬は大きな降 雨はなかったものの, 8 月中旬に台風 10 号の影響により 18 日に佐賀市で $54 \mathrm{~mm}$ の降雨があった. 下旬には前線が九州 北部に停滞し, 30 日から 31 日には佐賀市で 81mm の降雨 が観測された.これらの降雨により 3 か月程度の長期の密度 成層の形成が観測されている. 一方, 最も流量が小さかった 年は 2008 年であり, $98.6 \mathrm{~m}^{3} / \mathrm{sec}$ であった. 水産総合研究セン ターおよび佐賀大学 ${ }^{11)}$ によと, 2008 年は強い風が吹かず, 降雨が少なかったことが報告されている.

解析期間中の筑後川平均流量と潮流振幅 $\left(\mathrm{M}_{2}\right)$ には負の 相関関係 $\left(\mathrm{R}^{2}=0.525\right)$ が見られた(図-6). また, 表層と底層の 密度差と筑後川流量との間には相関関係が見られた $\left(\mathrm{R}^{2}=0.397\right)$. さらに, 表層と底層の密度差と潮流振幅 $\left(\mathrm{M}_{2}\right)$ に は高い負の相関 $\left(\mathrm{R}^{2}=0.716\right)$ が見られた (図-7). 表層と底層 の密度差は2008年と2009年が $2 \mathrm{~kg} / \mathrm{m}^{3}$ 程度で最も小さく, 2006 年は $5 \mathrm{~kg} / \mathrm{m}^{3}$ 程度で最も大きかった。

\section{(3) 密度成層の形成亡底層D0の経年変化}

成層状態は流速の3乗で変化する。図-8に潮流振幅 $\left(\mathrm{M}_{2}\right)$ の3乗と底層DO飽和度との関係を示す. 両者には強い 相関関係 $\left(\mathrm{R}^{2}=0.766\right)$ がみられた. 平均DO飽和度は経年的に 大きく変動しており, 2006年および2012年が低く, それぞれ 
39.7\%, 30.6\%であった. 一方, 最も高い值を示したのは2009 年であり, 63\%であった. 堤ら ${ }^{12)}$ が示したような貧酸素化が 年々進行する傾向はみられなかった. また, 表層と底層の密 度差と底層DO飽和度との相関関係が見られた $\left(\mathrm{R}^{2}=0.654\right)$. 残差流の大きさと底層DO飽和度との相関関係は見られなか った $\left(\mathrm{R}^{2}=0.276\right)$.

\section{4. 考察}

(1) 潮流振幅 $\left(M_{2}\right)$ と密度成層との関係

淡水流入や高密度水塊の底層貫入による密度成層の形 成に伴う表層から底層への酸素供給の減少が貧酸素水塊 の形成には重要な役割を果たす. Simpson and Hunter ${ }^{13)}$, 塚本・柳 ${ }^{14)}$ は流速が成層状態の変化に及ぼす影響を明ら

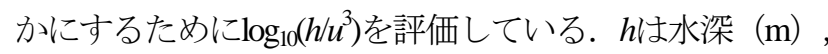
uは流速（m/sec）であり，流速の成層状態へ影響は $u$ の3 乗で変化する. 潮流振幅 $\left(\mathrm{M}_{2}\right)$ の3乗と調和分解期間中 の表層と底層の密度差との間には相関関係が見られたた め（図-7），潮流（ $\mathrm{M}_{2}$ ）が大きいと鉛直混合が大きく なることが示唆される．2006年と2012年は淡水流入によ る密度成層強度（表層と底層の密度差）が大きく底層流 速が小さい（図-3）。また，2009年は時化による鉛直混 合によって密度成層強度は小さくなっていた（図-7） ${ }^{11)}$. したがって，潮流振幅が鉛直混合および密度成層強度に 影響されたものと考えられる.

近年では，潮流は鉛直混合のみならず，河口循環流の 形成にも影響することが明らかになっている. 小田巻5, 15)は河口循環流の形成が潮流棈円へ及ぼす影響を明らか にするために有明海で現地観測を行い，河川からの浮力 による水平方向の圧力公配が河口循環流を形成させ，圧 力勾配の上げ潮と下げ潮による差異から底層における潮 流楕円の長軸を低下させることを河口循環流と振動流

(潮流) のベクトル合成で説明した. また，白木・柳 ${ }^{16)}$ は，河口循環流は潮汐振幅の変化に対してろつのステー ジにおいてその強弱が異なることを数值計算で示してい る. すなわち, 強成層では潮汐振幅が大きくなるにつれ て鉛直混合が強くなるために河口循環流は弱くなること， 緩成層ではTidal strainingが重要となり鉛直混合が強化さ れるにもかかわらず河口循環流は潮汐振幅の増大ととも に強くなること，弱成層河口循環流に対して逆向きに作 用する潮汐応力と鉛直混合の強化のために河口循環流が 弱くなることを明らかにしている．本研究でも小田巻 ${ }^{15}$ と同様に，河川流量が大きかった2006年と2012年は底層 潮流振幅が最も小さくなっていた（図-3，図-5）.

2006年と2012年は多量の淡水流入により河口循環流が顕 著だったことが考えられ，逆に2009年は淡水流入が小さ かったためにバロトロピックなモードとなり河口循環流

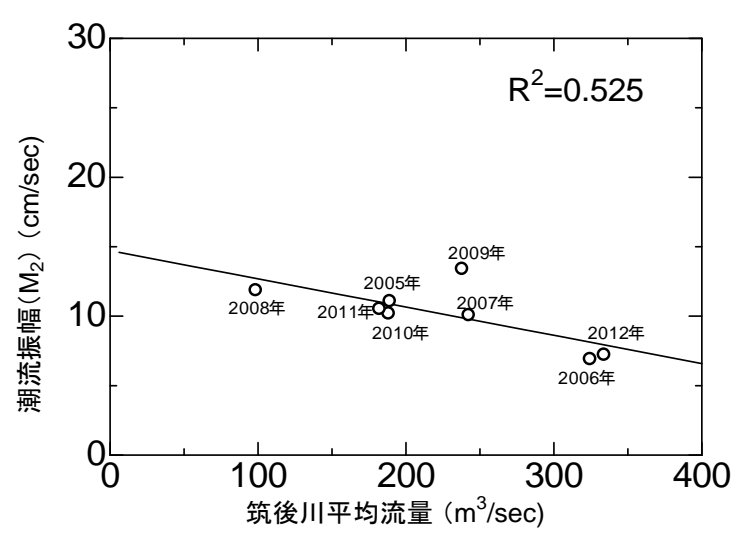

図-6 筑後川平均流量と潮流振幅 $\left(\mathrm{M}_{2}\right)$ との関係

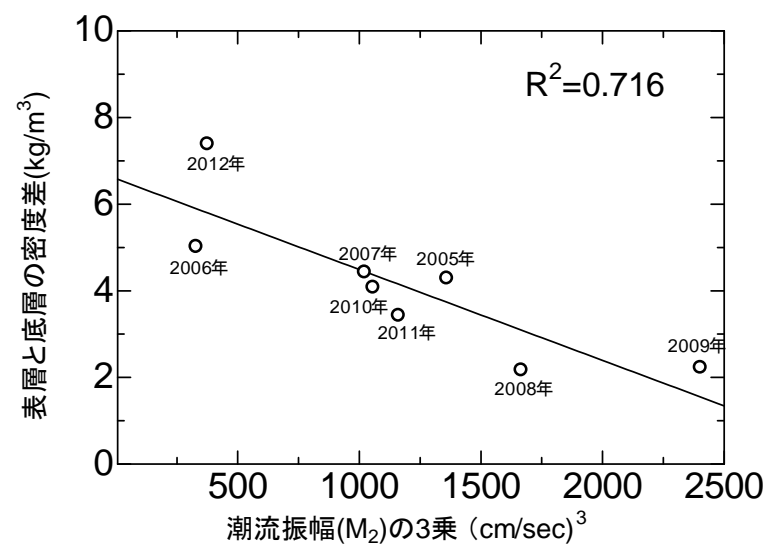

図-7 潮流振幅 $\left(\mathrm{M}_{2}\right)$ の3 乗と密度差との関係

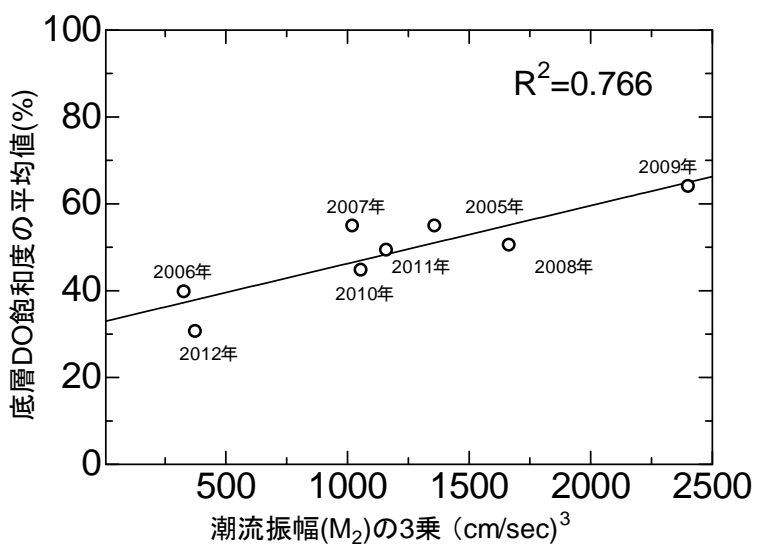

図-8 潮流振幅 $\left(\mathrm{M}_{2}\right)$ の3 乗と底層 DO飽和度との関係

が顕著に形成されず，底層の潮流振幅が小さくなったも のと考えられる。また，万田られは，有明海中央部にお ける物質輸送過程を現地観測にて検討しており，潮流の 減少により，夏季の河口循環流による物質輸送量は増加 していること，夏季では河口循環流の塩分輸送に対する 寄与率は6割程度であることを明らかにしており，本研 究の結果と矛盾しない. 


\section{（2）潮流振幅（ $\left.\mathbb{M}_{2}\right)$ と底層D0との関係}

有明海湾奥西部海域の干潟縁辺域における貧酸素水塊 の短期変動については，徳永ら ${ }^{17)}$ や元ら ${ }^{18)}$ が大潮一小 潮周期の変動が見られることや小潮期に底層DOが急激 に低下することを明らかにしており，その変動機構につ いては強い潮流による鉛直混合と表層からの酸素供給の 減少，懸濁物および堆積物の酸素消費速度などの素過程 の大小が重要であることを明らかにしている．表層と底 層の密度差と底層DOには相関関係が見られたことから, 密度成層の形成が底層DOの経年変動に重要な役割を果 たすことが示唆された。

有明海では月の昇降点運動に伴う18.6年周期の $\mathrm{M}_{2}$ 潮の 潮汐変動が水質変動に重要な役割を果たすことが報告さ れている. 田井ら（2006）6大浦の潮汐データを用い てf值 $\times \mathrm{M}_{2}$ 潮の潮汐振幅の長期変動を示した。2008年以 降 $\mathrm{f}$ 值 $\times \mathrm{M}_{2}$ 潮の潮汐振幅は上昇しており（図-4），底層 DOとの関係を検討したが明確な関係性はみられなかっ たことから，単純な潮汐振幅の減少だけでは底層DOの 経年変動は説明できないことが示唆される. その理由と して，一般的に潮汐変動は潮流の変化を示唆するもので あり空間代表性が高いものであるが，局所的な評価には 不向きであり潮流での評価が必要であること年が考えら れる. また, 河口循環流の形成には淡水流入量や地球自 転や地形の効果，急激な淡水流入量の変化や大潮・小潮 などの非定常性も関係するためと考えられる ${ }^{16)}$.ただし 月の昇降点運動に伴う18.6年周期の $\mathrm{M}_{2}$ 潮の潮汐変動も潮 流振幅に重要な役割を果たすため, 今後もモニタリング を継続して淡水流入に伴う潮流振幅変動の寄与と 18.6 年 周期変動の寄与を分離することが必要であると考えられ る.

\section{（3）筑後川からの流入負荷と底層D0との関係}

底層DOは上記の物理的作用のみならず植物プランク トンの増殖と枯死・沈降，酸素消費過程などの生物化学

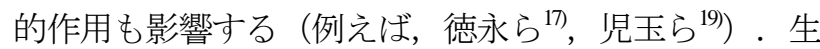
物化学的な影響の基点は河川からの栄養塩の流入である。 筑後川から流入する淡水流入量と窒素のL-Q式20)から調 和解析期間中の窒素流入負荷を算出し，底層DOとの相 関関係を検討した結果有意な相関関係が見られた $\left(\mathrm{R}^{2}=0.55\right)$. したがって，生物化学的作用（植物プラ ンクトンの増殖と枯死・沈降, 酸素消費過程) も底層 DOの低下に寄与しているものと考えられる．また，河 川からの負荷と底層DOとの相関関係から河川から流入 した栄養塩等から貧酸素化までの時間スケールが比較的 小さいことが示唆され，これは他の閉鎖性海域に比べ有 明海湾奥における基礎生産量が高いことやDO低下速度 が約 $1 \mathrm{mg} / \mathrm{L} / \mathrm{day}$ であり，数日程度で貧酸素化する既往の 知見と矛盾しない ${ }^{21)}$, 17)。山口・速水22) は，浅海定線調査
および河川流量変動との関係を統計的に解析し, 出水が 継続するとDINは上昇し，DIP濃度は低下することを明 らかにしている。一般的に，DIPは貧酸素化によって溶 出フラックスが増加する。 さらに，底層DO飽和度が高 かった2009年は流入負荷が最も小さいことから（図-5）， 貧酸素水塊の形成を抑制するためには，河川からの流入 負荷（DIN）や海底からの栄養塩溶出フラックスの削減 が有効であることが示唆される. さらに，有明海湾奥西 部の干潟縁辺域においては流入負荷と底層DOとの間に 相関関係が見られることから， linear Recoveryに分類され ると考えられ，流入負荷の削減と海底からの溶出フラッ クスを削減することにより，貧酸素水塊の形成は線形的 に減少することが示唆される.

\section{5. おわりに}

有明海湾奥西部の干潟縁辺域を中心に形成する貧酸素 水塊の経年変動特性と潮流との関係を明らかにするため に2005年から2012年の夏季に底層流速および底層DO等 の水質の現地観測を行った。流速の調和解析を行った結 果，いずれの年も $\mathrm{M}_{2}$ 潮が卓越しており，東西成分より も南北成分が卓越していた. 潮流振幅 $\left(\mathrm{M}_{2}\right)$ は2009年 が大きく，2006年と2012年が小さかった，平均底層DO は2006年および2012年が最も低く，2009年が最も高い值 を示した。潮流振幅 $\left(\mathrm{M}_{2}\right)$ と密度差, 潮流振幅 $\left(\mathrm{M}_{2}\right)$ の3乗と平均底層DOのとの間には相関関係が見られたこ とから，有明海湾奥西部の干潟縁辺域では，生物化学的 作用のみならず淡水流入による河口循環流の形成とそれ による潮流振幅の変化が貧酸素水塊の形成に重要な役割 を果たしていることが示唆された．今後は，他の分潮の 寄与，内部潮汐の影響，生物化学的現象（基礎生産，懸 濁物の輸送，酸素消費過程）の経年変化との関係性につ いて検討する必要があると考えられる。また，2008年は 淡水流入が最も少ないにもかかわらず，潮流振幅は2009 年が最も大きかった理由は不明であり，短期変動の検討 が必要であると思われる.

謝辞：本研究を行うにあたり，東京工業大学大学院情報 理工学研究科灘岡和夫教授, 佐賀大学低平地沿岸海域研 究センター速水祐一准教授および長崎大学大学院水産・ 環境科学総合研究科万田敦昌准教授に有益な議論を行っ て頂いた，記して感謝の意を表します.

\section{参考文献}

1) Diaz, R. J. and Rosenberg, R. : Spreading dead zones and consequences for marine ecosystems, Science, Vol. 321, pp. 
926-929, 2008.

2) Nilsson, H. C. and Rosenberg R. : Hypoxic response of two marine benthic communities, Mar. Ecol. Prog. Ser., Vol. 115, pp. 209-217.

3) Kemp, W. M., Testa, J. M., Conley, D. J., Gilbert, D. and Hagy J. D. : Temporal responses of coastal hypoxia to nutrient loading and physical controls, Biogeosciences, Vol. 6 , pp. 2985-3008, 2009.

4) 速水祐一, 山本浩一, 大串浩一郎, 濱田浩治, 平川 隆一，宮坂仁，大森浩二：夏季の有明海奥部におけ る懸濁物輸送とその水質への影響, 海岸工学論文集, Vol. 53, pp.956-960, 2006.

5) 小田巻実, 大庭幸広, 柴田宣昭 : 有明海の潮流新旧 比較観測結果について, 海洋情報部研究報告, Vol. 39, pp. 33-61.

6) 田井明, Mukhsan Putra Hatta, 矢野真一郎, 齋田倫範, 小松利光 : 諫早湾湾奥の締切りが有明海の潮汐・潮 流に与えた影響, 海岸工学論文集, Vol. 53, pp.331335, 2006.

7) 万田敦昌, 兼原壽生, 青島隆, 筒井博信, 木下宰, 中田英昭, 柳哲雄 : 有明海中央部における物質輸送 過程の季節変動, 海の研究, Vol. 15 (6), pp. 465-477, 2006.

8) 松野健, 中田英昭 : 有明海の流れ場を支配する物理 過程, 沿岸海洋研究, Vol. 42, pp. 11-17, 2004.

9) 中野猿人 : 潮汐學, 古今書院, pp. 528-529, 1940.

10）環境省: 平成 21 年度環境省請負業務「有明海貧酸素 水塊発生機構実証調査」報告書, 2008 .

11) 水産総合研究センター, 佐賀大学 : 平成 22 年度有明 海生態系回復方策検討調查（二枚貝類の環境浄化機 能解明調查）報告書，2010.

12）堤裕昭，堤彩，高松篤志，木村千寿子，永田紗矢香, 佃政則，小森田智大，高橋徹，門谷茂：有明海奥部
における夏季の貧酸素水発生域の拡大とそのメカニ ズム, 海の研究, Vol. 16(3), pp. 183-202, 2007.

13) Simpson, J. H. and Hunter, J. R. : Fronts in the Irish Sea, Nature, Vol. 250, pp. 404-406, 1974.

14）塚本秀史, 柳哲雄: 有明海の潮汐 - 潮流, 海と空, Vol. 78, pp. 31-38, 2002.

15) 小田巻実 : 河口循環流と潮流一潮流の鉛直分布に対 する重力循環の影響の可能性一, 沿岸海洋研究, Vol. 44, pp. 107-115, 2007.

16) 白木喜章, 柳哲雄 : 振動流による非線形性を考慮し た河口循環流の力学, 沿岸海洋研究, Vol. 44, pp. 129-135, 2007

17) 徳永貴久, 児玉真史, 木元克則, 柴原芳一：有明海 湾奥西部海域における貧酸素水塊の形成特性，土木 学会論文集 B2（海岸工学）, Vol. B2-65, pp. 10111015, 2009.

18) 木元克則, 西内耕, 岡村和麿 : 有明海における溶存 酸素分布, 月刊海洋, Vol. 35, NO. 4, pp. 261-265, 2003.

19）児玉真史, 徳永貴久, 木元克則, 柴原芳一：夏季の 有明海奥部における基礎生産速度と有機眯濁物質の 分解特性, 土木学会論文集 B2（海岸工学）, Vol. B2-65, pp. 1006-1010, 2009.

20)田中義人, 熊谷博史, 松尾宏, 中村又善 : 有明海に 流入する筑後川および矢部川の降水時流出と負荷量 変動, 用水と排水, Vol. 48, pp. 59-65， 2006.

21) 柳哲雄 : 有明海の低次生物生産構造 - ノリ不作問題 に関連して -, 応用数理, Vol. 12, pp. 49-53, 2002.

22) 山口創一, 速水祐一：有明海湾奥における出水後の 低塩分水塊の挙動およびその水質への影響, 沿岸海 洋研究, Vol. 46, pp. 161-173.

\section{BOTTOM DISSOLVED OXYGEN VARIATIONS IN THE SUMMER FROM 2005 TO 2012 IN THE WESTERN SUBTIDAL ZONE OF ARIAKE BAY}

\section{Takahisa TOKUNAGA, Akira TAI and Katsunori KIMOTO}

Monitoring of current and water quality were conducted in the summer from 2005 to 2012 in order to reveal the relationship between tidal currents and hypoxia in the inner western part of Ariake Bay. $\mathbf{M}_{2}$ component were largest in the 10 tidal components, and northern component were larger than eastern component every year from the result of harmonic analysis of bottom layer currents. Tidal current amplitude of $\mathrm{M}_{2}$ component on 2009 was highest, on 2006 and 2012 lowest in the 9 years. Average dissolved oxygen above the $0.2 \mathrm{~m}$ sediments on 2006 and 2012 were lowest, on 2009 highest. From the relationship between the tidal currents amplitude of $\mathbf{M}_{2}$ and stratification, between the tidal current amplitude of $\mathbf{M}_{2}$ and bottom average dissolved oxygen, estuarine circulation by freshwater input and tidal current variation has also an important role of occurrence of hypoxia in the inner western part of Ariake Bay. 